\title{
Prediction analysis of the degradation and the service life building components in artificial method neural network and ISO factor $15686-2$
}

\author{
Siti Aisyah*, Akhmad Aminullah, and H. Muslikh \\ Department of Civil and Environmental Engineering, Faculty of Engineering Universitas Gadjah Mada, Indonesia
}

\begin{abstract}
The research study reported in this paper aims to combine the Artificial Neural Networks with ISO 15686 Buildings and constructed assets - Service life planning, a framework-based approach to offering a more reliable deterioration forecasting more reliable for building. This paper discusses the existing data and develop a close relationship definition between factors affecting the condition of the service life of the building, the value of building condition and determine the level of degradation of the building component, also predicted the age of the building components in accordance with a specific time variables. Data examination conducted in this research is building condition data of student dormitory at the Universitas Gadjah Mada, the data will be used to calibrate the model of damage to consider a number of factors that influence. To help demonstrate the concept, factors affecting the decline is considered in the analysis of the design level, the level of implementation of the work, the indoor environment, the external environment, the level of care and conditions of use. Predictive analysis with artificial methods of neural network (ANN) with ISO factor input variables and factors age of the building components and the severity level of degradation of the building components $\left(S_{w}\right)$ as output, this will generate a calculation formula that shows the effect of each variable input to output. Predictive analysis carried out with the reverse approach in which after calculation formula obtained by ANN method, then the next step is to find the value of the variable age of the building components according to the value of degradation that has been determined.
\end{abstract}

\section{Introduction}

\subsection{Background}

Another type of asset management infrastructure is the implementation of maintenance and care building. Any assets of infrastructure development need maintenance and care to ensure that infrastructure building they can properly function and to make sure that component structures meet the requirements during their economic life. The main problems encountered in asset management infrastructure include:

1. The management of infrastructure assets has not been able to provide detailed information on the condition of the assets owned so that the maintenance and maintenance plan of the asset can not be established based on the priority scale.

2. The types of maintenance and maintenance of each category of asset damage have not been uniform, so the potential in which the same damage, but behaviour can set different treatments.
3. Lack of maintenance standards and maintenance of assets that can be applied in making decisions in asset management.

Based on these problems, it is necessary to identify early and predict the condition of building conditions regarding the preventive maintenance plan and corrective maintenance and regularly scheduled basis, in order to prevent the failure of building elements and minimize repair costs.

Flores-Colen, I., \& De Brito, J. (2010) explains that $a$ poor design of construction details, a bad choice of the façade materials (e.g. plaster with high porosity in a marine environment), its inadequate application, and inexistent maintenance are the core of current problems in buildings' façades [1].

This research its substance referring to bridge management pattern that is developing better by now. Bridge infrastructure management based computer system developed by the Directorate General of Binamarga form of Bridge Management System (BMS raises the idea that the system could be applied to the

* Corresponding author: ais aisyah@ugm.ac.id 
management of the building. Therefore, there needs to be a study related to the method of building management especially the aspects of maintenance and the care of the building conforming by established standards and are effective and efficient.

This research analysis predictions discusses the predictive analysis of the level of degradation and component service life of buildings taking into account the variables that affect the condition of the building, as a reference in determining the treatment plan.

The methodology used to support the analysis in this study is the ISO 15686 standard, namely Buildings and constructed assets - Service life planning (future serviceability and asset building construction). International Standard ISO 15686 provides information on general principles, frameworks, and methodologies to estimate the service life of building components, as well as the prediction to determine the maintenance time and replacement of components necessary for building the infrastructure (ISO 15686 part 1 of the Introduction of the Standard).

The method of calculation analysis to determine the predictive value of age serviceability of building components used in this study, conducted using Artificial Neural Network.in addition to determining the influence variable components used in the calculation analysis refers to the explanation in the standard document ISO 15686 part 2 of the Service life prediction procedures [2-3].

\subsection{Problem Formulation}

The problem can be formulated based on the description of the background that has been described above is how to identify the factors that affect the condition of the building, how to determine the level of degradation of a component of the building and how the formula can be used to predict the condition of service life of the building components on certain time.

\subsection{Objective}

The objective of this study is provide an explanation regarding:

1. Determination of the factors that affect the condition of the building service life.

2. How to calculate the value of the condition of the building and determine the level of degradation of the building components.

3. How to formulate a predictive value of a service life of building components in accordance with a specific time variable.

\subsection{Benefits Research}

Benefit of this research is to be able to determine the extent of degradation of a building component and predict the service life of a component of the building which is expected to be a reference to determine the best treatment strategy for the condition of the building.

\section{Theoretical}

\subsection{ISO 15686, Buildings and constructed assets - Service life planning (2011)}

The transition of ISO documents on building structures include [4]:

1. ISO 13823, General Principles on the Design of Structures for Durability (2008);

2. ISO 15686, Buildings and Constructed Assets Service Life Planning: Part 2, Service Life Prediction Procedures (2011); and

3. ISO 13823, General Principles on the Design of Structures for Durability, for the Purpose of This Ethiopian Standard (2012).

Factors that affect the service life of a component architecture according to the ISO 15686-2 document on Service Life Prediction Procedures, are [5-7]:

$$
\begin{aligned}
E S L C= & R S L C \text { factor } x A \text { factor } x B \text { factor } x C \text { factor } x \\
& D \text { factor } x \text { E factor } x F \text { factor } x \text { factor } G
\end{aligned}
$$

Each of these factors is described in accordance with the following picture [7]:

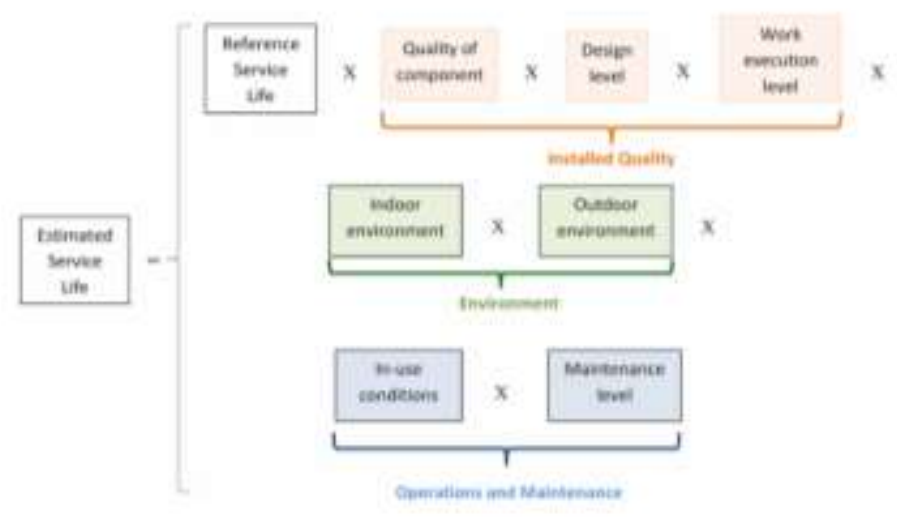

Fig. 1. Factors affecting service life, Edirisinghe, R.

Calculations to perform analysis using ANN method, factors affecting the level of degradation component qualitative building needs to be changed in a quantitative form, as input data in the calculation system.

This type of damage (defect) as a building wall components are as follows [8]:

1. Plaster crack

2. Stain

3. Water seepage

4. Paint peeling and blisters

5. paint and plaster patchy

6. Chipped

7. concrete and tiles crack

8. tiles falling / popping

Before performing a calculation by $\mathrm{ANN}$, the previous need to know the value of the level of degradation of a component having damaged. The calculation of the rate of degradation of the building components $\left(\mathrm{S}_{\mathrm{w}}\right)$ is as follows [9-12]: 


$$
S=\frac{\sum\left(A_{n} \times k_{n} \times k_{a, n}\right)}{A \times k}
$$

\section{Description:}

$\mathrm{S}$ (Severity of degradation) is the level of degradation of the building components.

$A_{n}$ (Area affected by defect) is the area that is damaged.

$\mathrm{K}_{\mathrm{n}}$ (Degradation level) is a multiplier for any damage.

$\mathrm{K}_{\mathrm{a}, \mathrm{n}}$ (Relative importance of the defects detected) is the coefficient for the component that is considered the most material.

$\mathrm{K}_{\max }$ is the highest degradation to a component being examined.

$\mathrm{A}$ is the total area of a component.

\subsection{Expert System Algorithm}

According to a general description of a service life calculation analysis by ANN building components can be described as in the following Figure 2 [12]:

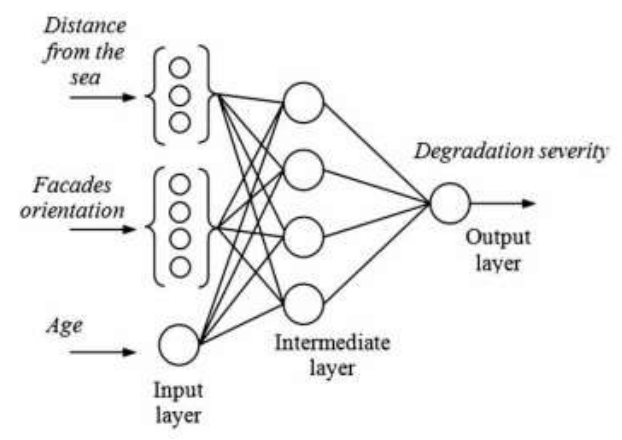

Fig. 2. Schematic analysis by ANN, Dias, JL, Silva, A., Chai, C., Gaspar, PL, \& De Brito, J.

\subsection{Regulation of the Minister of Public Works and Public Housing and the Building Condition Assessment of Governance How Building Maintenance}

Regulation of the Minister of Public Works No. 24 Year 2008 contains an explanation regarding the implementation of the basic rules of maintenance and upkeep of buildings. In which includes the classification of the level of damage and the method of maintenance and care. As for the types of damage to buildings classified in the following levels:

1. Slight damage

a. Slight damage is damage, especially on nonstructural components, such as roofing, ceiling, floor coverings, and wall charger.

b. Treatment for mild damage level, the fee is a maximum of $35 \%$ of the highest unit price of building a new building which is applicable, for the type / class and the same location.

2. Damage was

a. Moderate damage is damage to most of the nonstructural components, or structural components such as roof structure, floor, and others. b. Treatment for moderate damage level, the fee is a maximum of $45 \%$ of the highest unit price of building a new building which is applicable, for the type/class and the same location.

3. Heavy damage

a. Heavy damage is damage to most of the components of the building, both structural and non-structural when once fixed can still function as well as it should.

b. It costs a maximum of $65 \%$ of the highest unit price of building a new building which is applicable, for the type/class and the same location.

\section{Methods}

Research sites located within the Universitas Gadjah Mada, which type of building was a survey is kind of a uniform tenement the rent (flat) work public works of the Ministry of Public Works and Public Housing (Kementerian PU-PR).

Research step is divided into your five steps:

1. Research data collection phase

2. Stage of determining the conditions at each of the building component

3. Stage analysis of the extent of degradation of the building component

4. Analysis of factors influence the degradation phase of building components in accordance with ISO using ANN method

5. Of calculation estimated life stage serviceability of a building component.

\section{Discussion}

The discussion conducted on as many as 100 variations of a building wall component data degraded.

\subsection{The calculation of the rate of degradation $\left(S_{w}\right)$}

The calculation of the value of the degradation of the components of building walls is done by the following formula [12]:

$$
S=\frac{\sum\left(A_{n} \times k_{n} \times k_{a, n}\right)}{A \times k}
$$

Table 1. This type of damage and the coefficient value

\begin{tabular}{|c|l|c|c|c|c|}
\hline \multirow{2}{*}{ no } & \multirow{2}{*}{$\begin{array}{c}\text { Damage Type } \\
\text { Component }\end{array}$} & \multicolumn{2}{|c|}{ Component Size } & $\begin{array}{c}\text { Weight } \\
\text { Damage }\end{array}$ & $\begin{array}{c}\text { Visible } \\
/ \\
\text { Non- } \\
\text { Visible }\end{array}$ \\
\cline { 3 - 6 } & & $\begin{array}{c}\text { Total } \\
(\mathrm{An}) \mathrm{m} 2\end{array}$ & $\begin{array}{c}\text { Damage } \\
\text { (Vn) } \mathrm{m} 2\end{array}$ & (Ka, n) & $\begin{array}{c}\text { Kn } \\
\text { (0 to 4) }\end{array}$ \\
\hline 1 & Wall & 26099.31 & & & 2 \\
\hline a. & Plaster crack & & 8801.61 & 0.1 & 2 \\
\hline b. & stain & & 11516.56 & 0.1 & 1 \\
\hline c. & $\begin{array}{l}\text { Water } \\
\text { seepage }\end{array}$ & & 4034.96 & 0.1 & 4 \\
\hline d. & $\begin{array}{l}\text { paint peeling } \\
\text { and blister }\end{array}$ & & 20160.73 & 2 & \\
\hline
\end{tabular}




\begin{tabular}{|c|l|c|c|c|c|}
\hline & paint & & & & \\
\hline e. & $\begin{array}{l}\text { Paint and } \\
\text { plaster patchy }\end{array}$ & & 5473.36 & 4 & 1 \\
\hline f. & chipped & & 19826.82 & 0.5 & 4 \\
\hline g. & $\begin{array}{l}\text { Concrete and } \\
\text { tiles crack }\end{array}$ & & 12823.45 & 3 & 2 \\
\hline h. & $\begin{array}{l}\text { tiles falling / } \\
\text { popping }\end{array}$ & & 4822.47 & 4 & 1 \\
\hline
\end{tabular}

From the coefficient at each type of damage as listed in Table 1 above, can further degradation values obtained for a building component. The results of the degradation value and the wall component damage level category for 100 sample data can be seen in the following Table 2 :

Table 2. Wall components degradation Value

\begin{tabular}{|c|c|c|c|}
\hline No & Condition & $\begin{array}{c}\text { Average Value } \\
\text { Degradation } \\
\left(\mathrm{S}_{\mathrm{w}}\right)\end{array}$ & $\begin{array}{c}\text { Percentage of } \\
\text { Total Sample }\end{array}$ \\
\hline 1 & Good & $7.88 \%$ & $8 \%$ \\
\hline 2 & $\begin{array}{c}\text { Damaged } \\
\text { Light }\end{array}$ & $15.53 \%$ & $50 \%$ \\
\hline 3 & $\begin{array}{c}\text { Damaged } \\
\text { Medium }\end{array}$ & $25.13 \%$ & $42 \%$ \\
\hline
\end{tabular}

\subsection{Analysis method of Artificial Neural Network (ANN) using ISO 15686 as a variable factor inputs}

34 input variables that are used to perform analysis using ANN method. The variables are grouped as follows:

1. Size component (X1);

2. The area based on the type of damage (X2, X3,... X9);

3. The weight of each type of damage $(\mathrm{Ka}, \mathrm{n})(\mathrm{X} 10$, $\mathrm{X} 11, \ldots \mathrm{X} 17)$;

4. Factors that damage is visible/nonvisible (Kn) (X18, X19 ... .X25);

5. Factors ISO (X26, X27, ... .X32);

6. Age Plans/Reference Service Life (RSL) (X33); and

7. Age of Existing Components (X34).

In addition, for the output variable is the value of the building component degradation $\left(\mathrm{S}_{\mathrm{w}}\right)$ as in Table 2 .

The analysis of the degradation of the building wall components with ANN method is detailed as follows:

1. Incorporate variable input and output variables in Matlab program.

2. Running data by ANN composition analysis, hidden layers numbered 1 and the number of neurons numbered 2, as seen in Figure 3.

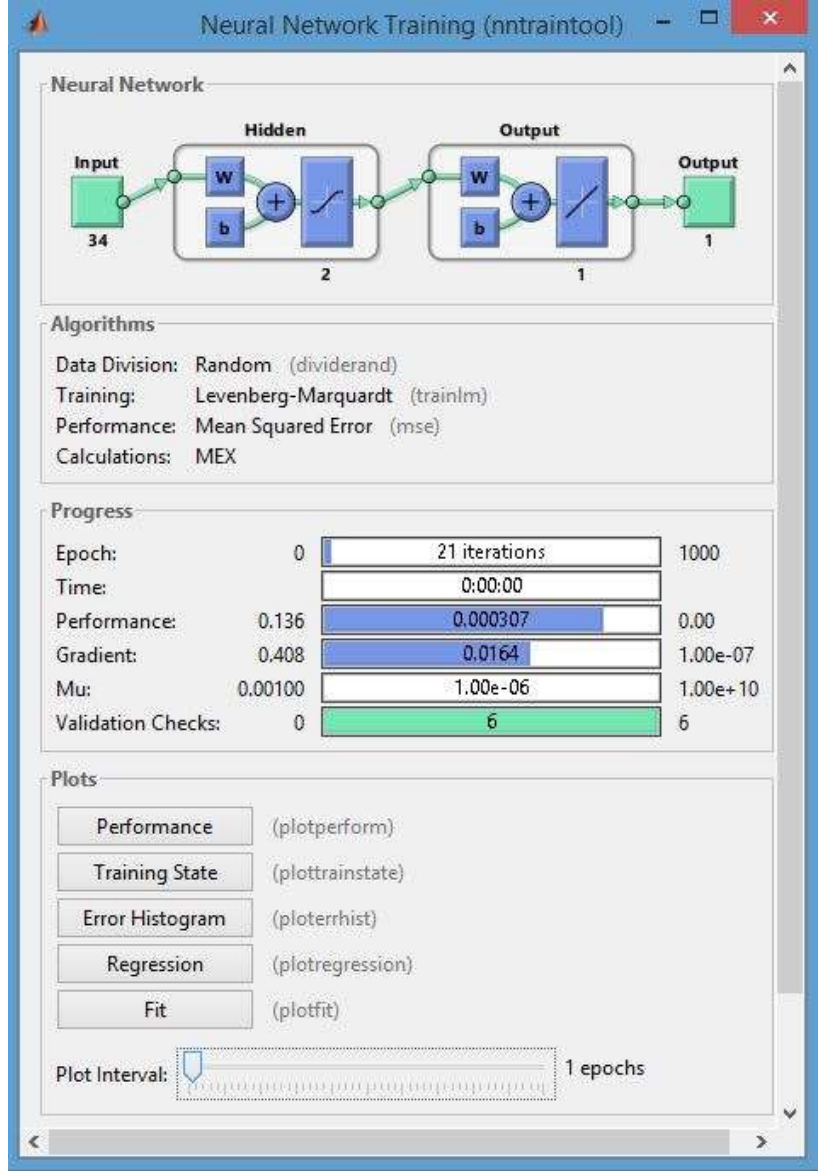

Fig. 3. The number of hidden layers and neurons

3. From the running process on the result of 100 testing sample data obtained result is coefficient of weight values at layer 1 , layer 2 , the coefficient value of bias on layer 1 and 1 , as summarized in Table 3 below:

Table 3. Coefficient of results of running JST

\begin{tabular}{|c|c|r|r|r|l|}
\hline Var & \multicolumn{2}{|c|}{ Thickness layer 1 } & $\begin{array}{c}\text { Thickness } \\
\text { layer 2 }\end{array}$ & bias 1 & bias 2 \\
\hline $\mathrm{X} 1$ & -0.854 & -0.155 & -0.135 & 2.131 & 0.101 \\
\hline $\mathrm{X} 2$ & -0.315 & -0.013 & 1.464 & -0.021 & \\
\hline $\mathrm{X} 3$ & -0.123 & 0.163 & & & \\
\hline $\mathrm{X} 4$ & -0.429 & -0.119 & & & \\
\hline $\mathrm{X} 5$ & -0.555 & 0.137 & & & \\
\hline $\mathrm{X} 6$ & -0.821 & 0.139 & & & \\
\hline $\mathrm{X} 7$ & -1.499 & -0.015 & & & \\
\hline $\mathrm{X} 8$ & -0.776 & -0.045 & & & \\
\hline $\mathrm{X} 9$ & 0.709 & 0.163 & & & \\
\hline $\mathrm{X} 10$ & 0.419 & -0.009 & & & \\
\hline $\mathrm{X} 11$ & -0.031 & -0.001 & & & \\
\hline $\mathrm{X} 12$ & 0.616 & 0.034 & & & \\
\hline $\mathrm{X} 13$ & 0.340 & 0.057 & & & \\
\hline
\end{tabular}




\begin{tabular}{|l|r|r|l|l|l|}
\hline X14 & -0.455 & 0.021 & & & \\
\hline X15 & -0.335 & 0.013 & & & \\
\hline X16 & -0.057 & 0.013 & & & \\
\hline X17 & 0.254 & 0.020 & & & \\
\hline X18 & -0.025 & 0.024 & & & \\
\hline X19 & 0.995 & -0.066 & & & \\
\hline X20 & -0.635 & 0.061 & & & \\
\hline X21 & -0.232 & 0.017 & & & \\
\hline X22 & 0.257 & 0.214 & & & \\
\hline X23 & -1.062 & -0.016 & & & \\
\hline X24 & -0.282 & 0.199 & & & \\
\hline X25 & 0.979 & 0.191 & & & \\
\hline X26 & 0.197 & -0.036 & & & \\
\hline X27 & -0.074 & -0.016 & & & \\
\hline X28 & -0.080 & -0.017 & & & \\
\hline X29 & -0.351 & -0.019 & & & \\
\hline X30 & -0.173 & 0.035 & & & \\
\hline X31 & 0.554 & 0.009 & & & \\
\hline X32 & 0.334 & 0.033 & & & \\
\hline x33 & 1 & 1 & & \\
\hline X34 & 0.344 & -0.003 & & \\
\hline
\end{tabular}

4. In addition to the weights and biases as the output value of running is the regression value obtained in the process of data validation is 0.96235 . The regression results as noted in the graph below:

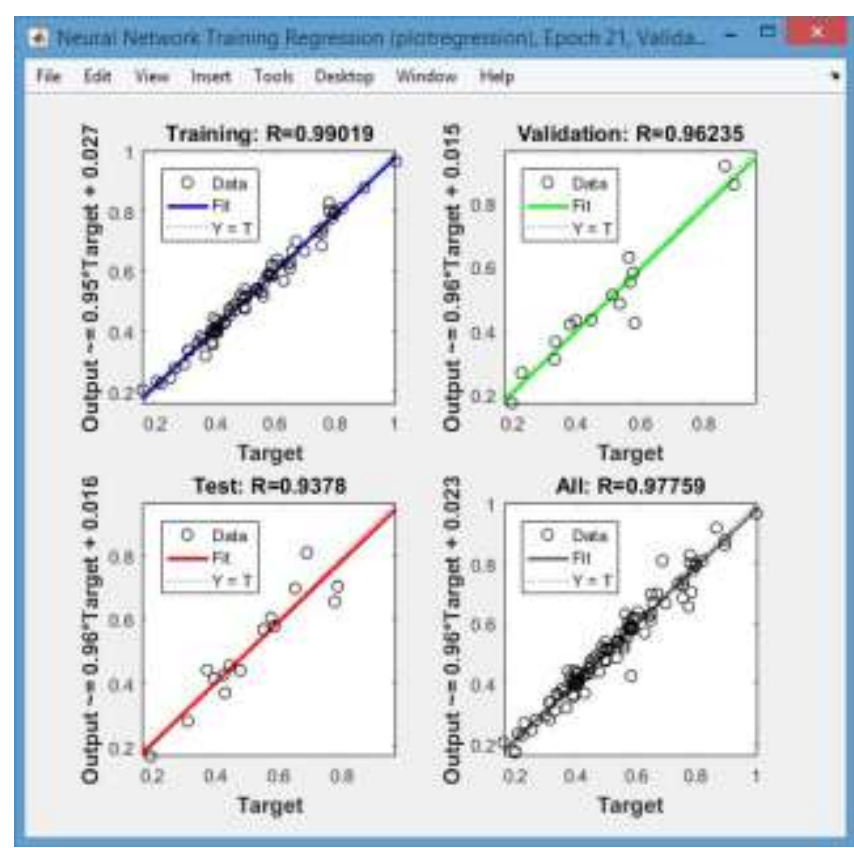

Fig. 4. Regression results of running JST Value
Formula to calculate the age of the building components on the value of certain degradation is:

$Z_{i n j}=(X i * V i j)+b i j$

$Z i=2 /\left(1+\operatorname{Exp}\left(-2 * Z_{i n j}\right)-1\right.$

$Y_{k}=(Z i * W i j)+b i j \quad(Y$ output $)$

The result from calculate of degradation is:

Table 4. Wall components degradation Prediction

\begin{tabular}{|c|c|c|}
\hline No & Age & $\begin{array}{c}\text { Value of Degradation } \\
\left(\mathrm{S}_{\mathrm{w}}\right)\end{array}$ \\
\hline 1 & 35 & $43.8 \%$ \\
\hline 2 & 38,5 (exixting) & $43.91182 \%$ \\
\hline 3 & 39 & $43.94131 \%$ \\
\hline 4 & 40 & $44.02425 \%$ \\
\hline 5 & 41 & $44.1708 \%$ \\
\hline 6 & 42 & $44.4997 \%$ \\
\hline 7 & 43 & $45.91162 \%$ \\
\hline
\end{tabular}

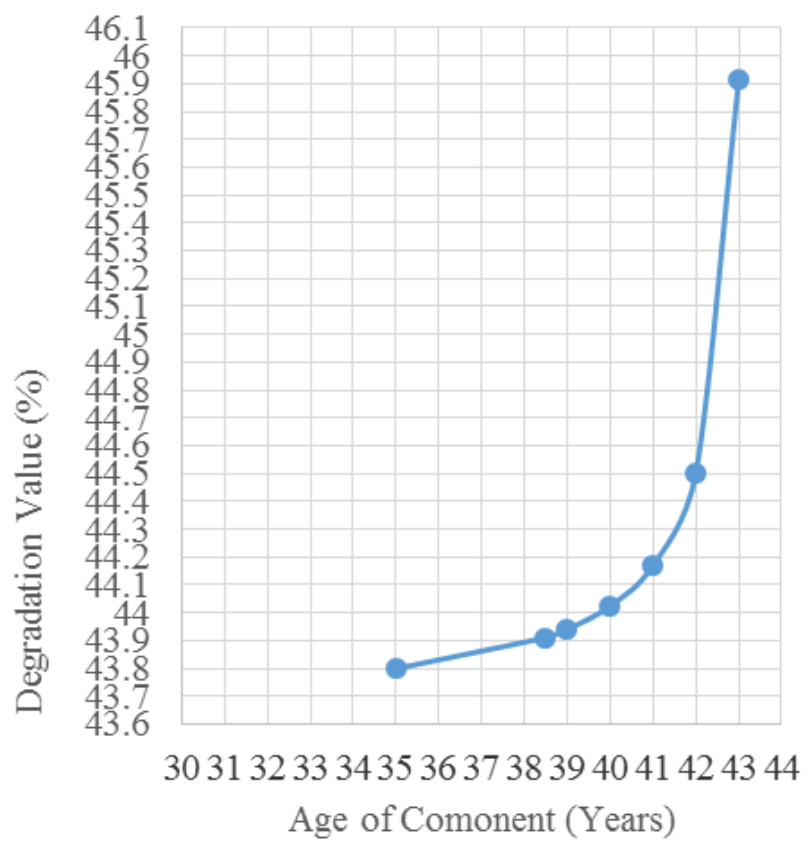

Fig. 5. Prediction Graph of Degradation Value

\section{Conclusion}

From the results of the analysis performed, we concluded the following results are from the analysis of 100 samples of the condition of building wall 
components, obtained empirical formula with 34 variables that influence to assess the level of degradation that is $Y_{k}=0.1012+\left(-0.1349 Z_{1}\right)+\left(1.4643 Z_{2}\right)$.

From the results of the activity a condition by a wall with existing age some 38.5 years obtained the value of degradation is $43,912 \%$ so that it can be categorized into the condition are heavily damaged. And the results of prediction components to a condition the wall that was 38.5 years such as the point of (2), has a maximum service life of 43 years as described in Figure 5.

\section{References}

1. Flores-Colen, I., \& De Brito, J. 24, 1718-1729. (2010)

2. Moreno, SH. 4, 5-11. (2012)

3. Marteinsson, B. 31, 416-426. (2003)

4. Federal Democratic Republic of Ethiopia. (2008)

5. Serralheiro, MI, de Brito, J., \& Silva, A. 133, 261274. (2017)

6. Kalamees, T. 9, 635-643. (2002)

7. Edirisinghe, R., Setunge, S., \& Zhang, G. 31, 1-9. (2015)

8. Chong, W., ASCE, M., \& Low, S. 20, 213-221. (2006)

9. Magos, M., Brito, J. De Gaspar, PL, \& Silva, A. 49 , 5209-5225. (2016)

10. Silva, A., De Brito, J., \& Gaspar, PL. 22, 165-174. (2012)

11. Ximenes, S., de Brito, J. Gaspar, PL, \& Silva, A. 48 , 2235-2249. (2015)

12. Dias, JL, Silva, A., Chai, C., Gaspar, PL, \& De Brito, J. 42 , 371-380. (2014) 